\title{
Laser in wounds: knowledge translation to an effective and innovative nursing practice
}

\author{
Laser em feridas: translação do conhecimento para uma \\ prática efetiva e inovadora na enfermagem \\ Láser em heridas: translación del conocimiento para uma \\ práctica efectiva e inovadora en enfermería
}

\section{Amália de Fátima Lucena $a^{a, b}$ \\ Taline Bavaresco ${ }^{c}$ \\ Dóris Baratz Menegond \\ Silvete Maria Brandão Schneider ${ }^{\mathrm{e}}$ \\ Rodrigo Madril Medeiros ${ }^{f}$ \\ Celia Mariana Barbosa de Souzag}

How to cite this article:

Lucena AF, Bavaresco T, Menegon

DB, Schneider SMB, Medeiros RM,

Souza CMB. Laser in wounds: knowledge translation to an effective and innovative nursing practice. Rev Gaúcha Enferm. 2021:42:e20200396. doi: https://doi. org/10.1590/1983-1447.2021.20200396
Universidade Federal do Rio Grande do Sul (UFRGS), Escola de Enfermagem, Programa de Pós- Graduação em Enfermagem. Porto Alegre, Rio Grande do Sul, Brasil.

Hospital de Clínicas de Porto Alegre (HCPA), Comissão do Processo de Enfermagem. Porto Alegre, Rio Grande do Sul, Brasil

C Universidade Federal do Rio Grande do Su (UFRGS), Escola de Enfermagem, Departamento de Enfermagem Médico-cirúrgica. Porto Alegre, Rio Grande do Sul, Brasil.

Hospital de Clínicas de Porto Alegre (HCPA), Comissão de Prevenção e Tratamento de Feridas. Porto Alegre, Rio Grande do Sul, Brasil

e Hospital de Clínicas de Porto Alegre (HCPA), Serviço de Enfermagem Ambulatorial. Porto Alegre, Rio Grande do Sul, Brasil

Hospital de Clínicas de Porto Alegre (HCPA), Gestão de assistencial de Convênios e Particulares. Porto Alegre, Rio Grande do Sul, Brasil

9 Hospital de Clínicas de Porto Alegre (HCPA), Serviço de Medicina Ocupacional. Porto Alegre, Rio Grande do Sul, Brasil

\section{ABSTRACT}

Objective: To describe the knowledge translation obtained through research of low-level laser therapy to wound treatment in the clinical practice.

Methods: Experience report about implementation strategies of this new technology in a university hospital, being an extension course the main one, developed between May and December 2019.

Results: The course was carried out by researchers in partnership with clinical nurses to 13 nurses from different areas with previous experience in wound care. Were taught 30 theoretical-practical class hours, part of them supervised in a real clinical setting, besides case studies. From that, an exclusive nursing consultation schedule of laser therapy was created at the outpatient and its use was also improved to patients admitted in several units of the hospital.

Final considerations: The knowledge translation developed about laser therapy allowed its implementation as a technology in wound treatment, qualifying the professional practice and benefiting the treatment of patients with wounds.

Keywords: Low-level light therapy. Translational medical research. Wound healing.

\section{RESUMO}

Objetivo: Descrever a translação do conhecimento obtido em pesquisa sobre terapia a laser de baixa potência para o tratamento de feridas na prática clínica.

Métodos: Relato de experiência sobre estratégias de implementação dessa nova tecnologia em um hospital universitário, sendo um curso de extensão a principal delas, desenvolvido entre maio e dezembro/2019.

Resultados: 0 curso foi realizado por pesquisadores em parceria com enfermeiros assistenciais para 13 enfermeiros de diferentes áreas e experiências no cuidado a pacientes com feridas. Foram ministradas 30 horas de aulas teórico-práticas, parte das mesmas supervisionadas em cenário clínico real, além de estudos de caso. A partir disso, foi criada uma agenda de consulta de enfermagem de laserterapia no ambulatório, bem como incrementado essa terapia em pacientes hospitalizados.

Considerações finais: A translação do conhecimento sobre laserterapia permitiu a implantação dessa tecnologia no tratamento de feridas, qualificando a prática profissional e beneficiando o tratamento de pacientes com feridas.

Palavras-chave: Terapia com luz de baixa intensidade. Pesquisa médica translacional. Cicatrização.

\section{RESUMEN}

Objetivo: Describir la traslación del conocimiento obtenido en investigación de la terapia con láser de baja potencia para el tratamiento de heridas en la práctica clínica.

Métodos: Relato de experiencia sobre estrategias para la implementación de esta nueva tecnología en un hospital universitario, con un curso de extensión desarrollado entre mayo y diciembre/2019.

Resultados: El curso fue realizado por investigadores en alianza con enfermeras especializadas para 13 enfermeros de diferentes áreas y experiencias en el cuidado con heridas. Fueran dados 30 horas de clases teórico-prácticas supervisadas en un entorno clínico real y estudios de casos. En consecuencia de esto, se creó consultas de enfermería de terapia láser, así como un aumento de esta terapia para los pacientes hospitalizados.

Consideraciones finales: La transferencia de conocimiento sobre la terapia con láser permitió la implantación de esta tecnología en el tratamiento de heridas, con práctica profesional calificada y beneficio el tratamiento de pacientes con heridas.

Palabras clave: Terapia por luz de baja potencia. Investigación en medicina traslacional. Cicatrización de heridas. 


\section{口INTRODUCTION}

Over the last decades, nursing has been using more effectively technologies for skin care and wound treatment, transforming, expanding and innovating care practice, as well as fostering professional qualification for the exercise of new practices ${ }^{(1-2)}$. Accompanying this knowledge evolution, recent Resolution of the Federal Council of Nursing (Conselho Federal de Enfermagem - COFEN) No. 567/2018 regulated the performance of the Nursing team, explaining the competence of nurses in participating in the evaluation, elaboration of protocols, selection and indication of new technologies in prevention and treatment of individuals with wounds ${ }^{(3)}$. Attached to this same Resolution, there is a specific description about the competence of these professionals to use new techniques and technologies such as Laser, Light Emitting Diode - LED, negative pressure therapy, electrotherapy, among others, through training ${ }^{(3)}$.

Thus, the diagnosis and care of wounds must be based on adequate protocols and carried out by professionals with technical and scientific knowledge, capable of identifying the underlying disease, intervening properly and evaluating the results obtained regarding wound healing, based on care standards $s^{(4)}$.

Among the types of interventions in wound treatment, laser therapy stands out as an adjuvant practice that still deserves to be explored by nurses, both in research and in care practice ${ }^{(5)}$. Studies show that low-level light therapy (LLLT) acts on cellular and biochemical events for wound repair in the phase of inflammatory reaction, cell proliferation and synthesis of elements that make up the extracellular matrix and the later period, called remodeling. Considered as a biomodulator in cells and tissues, it causes cell proliferation, tissue neoformation, revascularization, increased microcirculation, edema reduction and pain relief(6).

Corroborating these ideas, a literature review ${ }^{(7)}$ pointed out that among the positive effects of LLLT is tissue restitution, anti-inflammatory actions, analgesic and healing effects. Another review also identified that LLLT is an adjuvant treatment with action capable of accelerating the healing process of tissue injury and, even when there is no total healing of the lesion, it promotes an improvement that affects the patient's well-being ${ }^{(2)}$.

In view of this evidence and at the same time with few results obtained by studies with a robust design, a randomized clinical trial (RCT) was developed in a Brazilian university hospital, with 40 patients with venous ulcers, in order to compare the effect of adjuvant LLLT and conventional treatment in injury tissue repair. In the study, the positive effect of LLLT was proven through an assessment with standardized clinical indicators of the Nursing Outcomes Classification (NOC) $)^{(5,8)}$.

Based on the results of this study ${ }^{(5)}$, the challenge for researchers was to promote the knowledge translation in an interactive and dynamic way with nurses in the field where the study was developed, in order to integrate the use of a new technology into the clinical practice scenario.

Knowledge translation refers to the co-creation and sharing of knowledge with stakeholders, in order to support decision-making, policy changes and the provision of health services changes. This can imply actions such as the organization of protocols, incorporation and solidification of new care practices, which culminate in the transformation of doing in the profession, which has the patient as the main focus of interaction and care ${ }^{(9-10)}$.

It is known that obtaining research results is not enough, it is necessary to transfer the knowledge produced to change reality, providing the incorporation of discoveries into care decisions based on scientific evidence.

Thus, for the positive use of an innovative technology such as LLLT in tissue repair, there is a need to provide technical-scientific knowledge to nurses, in order to expand care with quality, resoluteness and safety. Because, according to COFEN Resolution No. 567/2018, nurses should only use this technology after training, which enables them with knowledge of physics, biophotonics, laser and biological tissue interaction, dosimetry, in addition to deepening the physiology of the wound healing process ${ }^{(3)}$.

Therefore, the authors of the aforementioned randomized clinical study ${ }^{(5,8)}$ sought strategies to translate the knowledge obtained. The development of this translation process occurred since the conception of the study, based on the interaction between researchers and clinical nurses ${ }^{(9-10)}$, seeking the transformation of care provided to patients with wounds.

Thus, the objective of this article is to describe the knowledge translation obtained in research on low-level laser therapy for wound treatment in clinical practice. Its purpose is to support the implementation of innovative research results in the practical field and, consequently, qualify care and fill existent gaps between research and health care.

\section{METHODS}

Retrospective experience report describing strategies for the knowledge translation to the LLLT implementation in wound treatment in a Brazilian university hospital, from May to December 2019. The translated knowledge is the 
result of research from a graduate program in Nursing, Scricto Sensu, from a federal university ${ }^{(5,8)}$, where an RCT was performed. During its development, which lasted four years, the researchers kept in constant contact with nurses from the institution where the study was conducted, sharing results from the different phases of the study, which can favor the knowledge translation, in this case, the LLLT implementation in wound treatment in that hospital.

Thus, the knowledge translation involved the interaction between researchers and nurses who work in the care of patients with wounds, whether in outpatient or hospital care, since the conception of the RCT to the implementation of its results in clinical practice. It is noteworthy that in this institution, the field of study, there is an outpatient schedule for nursing care to patients with wounds, and patients hospitalized with this type of injury also receive consulting services carried out by specialist nurses, to assist the care team in prevention and wound care.

For the execution of the knowledge translation phases, the researchers sought to know the institution's care scenario, evaluating the barriers and facilitators to the new practice. The research project budget also provided for the purchase of three low-level laser devices for use in the hospital.

Interventions for the knowledge translation related to LLLT in wound care started with educational meetings; quick improvement course for nurses during an event at the institution ${ }^{(11)}$; presentation and discussion of the study preliminary results in institutional events; elaboration of abstracts presented at events in partnership between researchers and nurses ${ }^{(11)}$. In sequence, a university extension course was organized for nurses with experience in wound care, called "Laser therapy application: what nurses need to know". It covered theoretical and practical aspects, in a total of 30 hours, developed in a real care setting, in order to ensure that at its end all participants were able to assess wounds, handling the device, fluency and radiance to be used in different tissues, as well as the safety in the use of low-level laser. In addition to the results of the previously mentioned research ${ }^{(5,8)}$, the course sought to meet what is regulated by COFEN Resolution No. 567/2018(3).

The course results analysis was done through positive feedback from the nurses and the clinical reasoning developed in the realization of real clinical cases that were presented by them at the end of the course.

The ethical aspects of this report were respected, maintaining the anonymity of institutional information and using only those that are already in public domain.

\section{RESULTS}

The positive evidence of LLLT identified in the RCT ${ }^{(5)}$, combined with the expertise of nurses in the treatment of wounds in the hospital studied and, especially, the need to improve and expand care for patients with wounds, triggered the main intervention of knowledge translation that was an extension course for nurses, with a certificate from the federal university to which the hospital is linked.

Thirteen nurses from the institution with experience in the care of patients with wounds participated in the course: one doctor, five masters and six specialists, who worked in different areas of the hospital (pediatrics, neonatology, surgery, clinic, outpatient, onco-hematology, cardiovascular and nephrology), but were not enabled to use the LLLT.

The course instructors were five nurses, being two researchers with a PhD; two clinical nurses with a master's degree and one with a specialist degree. All of them with certification for the application of Low-Level Laser Therapy and with knowledge and/or participation in some of the stages of the RCT that originated the results emphasized in the extension course.

The course called"Laser therapy application: what nurses need to know" had 30 theoretical-practical hours, with the main objective of training nurses to apply LLLT in the prophylactic and curative treatment of patients with acute or chronic tissue injuries. The course's objectives were also to promote nurses' knowledge about phototherapy and the current scientific evidence about the care of skin and tissue lesions, with discussion of real clinical cases and different protocols for the use of LLLT. In addition, it was guided the use of evaluation instruments for the tissue regeneration process, based on the Nursing Outcomes Classification - NOC ${ }^{(12)}$.

The course had two modules, the first with 14 hours of theoretical classes about the phototherapy bases: historical introduction of laser therapy, interaction of laser with biological tissue, mechanism of action of laser therapy with photobiomodulation therapy, dosimetric parameters, intravascular blood irradiation with modified laser, biosafety in the use of laser, research perspectives and scientific evidence, evaluation instruments of the tissue regeneration process based on NOC, prevention and healing of acute and chronic wounds. Photodynamic therapy, its mechanism of action and indications were also studied, with demonstration of the practical application and handling of the laser device.

The second module of the 16-hour course was divided into supervised practice in a real clinical setting and case report seminar. The LLLT was applied by the participants in 
outpatients and in inpatients with indication for intervention. Around 50 patients were treated, the main cases being pressure injuries, venous ulcers, diabetic foot and postoperative wound dehiscence. Low power laser devices with infrared $808 \mathrm{~nm}$, red $660 \mathrm{~nm}$ were used, with the consent of the patients for the intervention.

In addition to the LLLT application, the course participants evaluated the tissue regeneration process of the wounds, considering the moment before and after the intervention, using clinical indicators of the results of the NOC Wound healing: second intention and Tissue integrity: skin and mucous membranes with instrument adapted from the RCT.

After the supervised practices, a seminar was held in which nurses in training reported patients' cases and discussed LLLT clinical protocols.

The extension course enabled 13 nurses from the research field institution to apply LLLT, which made it possible to implement the use of this therapy as an adjuvant to the treatment of patients with acute and chronic wounds in different sectors of the institution. As a result, a LLLT Nursing consultation schedule was created in the outpatient clinic and the use of this therapy in hospitalized patients was increased.

It is worth mentioning that in this extension course, lesions of neoplastic origin were not included, as they have peculiar characteristics and require specific studies for the use of photodynamic therapy, including clinical indicators validated for this clinical scenario.

\section{DISCUSSION}

Skin care has always been in the scope of nursing work, including the prevention and treatment of wounds, with the nurse being responsible for planning and evaluating comprehensive and careful patient care, considering its biopsychosocial aspects.

In the hospital scenario, as well as in outpatient clinics, patients with wounds of different etiologies, whether acute or chronic, are common ${ }^{(13)}$. In all cases, the nurse plays an important role in their care, which requires knowledge and skills to act, keeping in mind the diagnosis, treatment, evaluation and different outcomes ${ }^{(14)}$.

Thus, in-service continuing education is essential, as it enables continuous learning of new knowledge, skills and attitudes in professional practice. Evidence-based practice results from research results that problematize clinical practice and culminate in the development of proposals that enable change in living realities and according to the competence of different health professionals ${ }^{(15)}$.

The knowledge translation reported in this article was the "driving force" for nurses to deepen their knowledge and training on new wound treatment techniques, driving a change in the real scenario of patient care with technical, ethical, and legal responsibility. Research without the knowledge translation stage does not have its results incorporated into the real care setting, which is an important phase, which goes beyond the methodological design of the study.

The limitation of this study is the fact that it was carried out in a single center, without parameters from other realities, which leads to the need for other similar initiatives in different Nursing scenarios.

\section{GINAL CONSIDERATIONS}

The knowledge translation developed about Low-Level LaserTherapy led to the implementation of this effective and innovative technology in the wound treatment, accelerating the use of research results developed in the institution and favoring the treatment of patients with a more qualified nursing staff. In addition, the nurses'qualification, according to COFEN regulations, for the application of Low-Level Laser Therapy in wounds, gives greater visibility to these professionals in the scenario of care for patients with skin and tissue injuries.

As it is an innovative practice for Nursing, based on research results in a real clinical scenario, this article offers a contribution to the qualification of care, teaching and research.

\section{DEFERENCES}

1. FitzpatrickE, Holland OJ, Vanderlise JJ. Ozone therapy for the treatment of chronic wounds: a systematic review. Int Wound J. 2018;15(4):633-44. doi: https://doi. org/10.1111/iwj.12907

2. Bavaresco T, Osmarin VM, Pires A, Moraes V, Lucena AF. Low-power laser therapy in wound healing. J Nurs UFPE. 2019;13(1):216-26. doi: https://doi. org/10.5205/1981-8963-v13i1a235938p216-226-2019

3. Conselho Federal de Enfermagem (BR). Resolução n 567/2018 de 29 de janeiro de 2018. Regulamenta a atuação da equipe de enfermagem no cuidado aos pacientes com feridas. Brasília, DF: COFEN; 2018 [cited 2020 Aug 12]. Available from: http://www.cofen.gov.br/resoluca0-cofenno-567-2018_60340.html

4. Barreto LNM, Cabral EM, Chies N, Almeida MA. Clinical indicators of nursing diagnosis Impaired physiological balance syndrome for organ donors. Esc Anna Nery. 2020;24(3):e20190341. doi: https://doi.org/10.1590/2177-9465-ean-2019-0341

5. Bavaresco T. 0 efeito do laser de baixa potência no tratamento de úlceras venosas avaliado pela Nursing Outcomes Classification (NOC): ensaio clínico randomizado [tese]. Porto Alegre (RS): Escola de Enfermagem, Universidade Federal do Rio Grande do Sul; 2018 [cited 2020 Aug 12]. Available from: https://www.lume.ufrgs. br/bitstream/handle/10183/186135/001082062.pdf?sequence=1\&isAllowed=y

6. Machado RS, Viana S, Sbruzzi G. Low-level laser therapy in the treatment of pressure ulcers: systematic review. Lasers Med Sci. 2017;32(4):937-44. doi: https://doi. org/10.1007/s10103-017-2150-9

7. Lima NEP, Gomes GDM, Feitosa ANA, Bezerra ALD, Sousa MNA. [Laser therapy low intensity in wound care and practice nurses]. Rev Enferm UFPI. 2018;7(1):50-6. Portuguese. doi: https://doi.org/10.26694/2238-7234.7150-56 
8. Osmarin VM, Bavaresco T, Lucena AF, Echer IC. Clinical indicators to evaluate the knowledge of patients with venous ulcer. Acta Paul Enferm. 2018;31(4):391-8. doi: https://doi.org/10.1590/1982-0194201800055

9. Oelke ND, Silva LMAD, Acosta AM. Knowledge translation: translating research into policy and practice. Rev Gaucha Enferm. 2015;36(3):113-7. doi:https://doi. org/10.1590/1983-1447.2015.03.55036

10. Crossetti MGO, Góes MGO. Knowledge translation: a challenge in provideing nursing care [editorial]. Rev Gaucha Enferm. 2017;38(2):e74266. doi: https:// doi.org/10.1590/1983-1447.2017.02.74266

11. Meneguzzo DT, Bavaresco T, Lucena AF. Resultados da laserterapia em pacientes com feridas crônicas. In: Processo de enfermagem - estratégia para resultados seguros na prática clínica: Anais do VIII Simpósio do Processo de Enfermagem e I Simpósio Internacional do Processo de Enfermagem; 2017 jun 8-9; Porto Alegre (RS), Brasil. Porto Alegre: HCPA; 2017 [cited 2020 Aug 18]. p. 90-2. Available from: https://lume.ufrgs.br/handle/10183/163252

\section{- Acknowledgments:}

To the National Council for Scientific and Technological Development (Conselho Nacional de Desenvolvimento Científico e Tecnológico - (NPq) and to the Research and Events Incentive Fund (Fundo de Incentivo à Pesquisa e Eventos - FIPE) of the Hospital de Clínicas de Porto Alegre.

\section{- Authorship contribution:}

Conceptualization: Amália de Fátima Lucena, Taline Bavaresco, Dóris Baratz Menegon, Silvete Maria Brandão Schneider, Rodrigo Madril Medeiros, Celia Mariana Barbosa de Souza.

Writing-original draft: Amália de Fátima Lucena, Taline Bavaresco, Dóris Baratz Menegon, Silvete Maria Brandão Schneider, Rodrigo Madril Medeiros, Celia Mariana Barbosa de Souza.

Writing-review \& editing: Amália de Fátima Lucena, Taline Bavaresco.

The authors declare that there is no conflict of interest.
12. Moorhead S, Johnson M, Maas ML, Swanson E, editors. Nursing Outcomes Classification (NOC). 5th. ed. St. Louis: Elsevier Mosby; 2014.

13. Menegon DB, Jansen MM, Scheneider SM, Barbosa FM, Scain S. Consulta de Enfermagem na prevenção e tratamento de feridas. In: Heldt E, organizador. Enfermagem ambulatorial: consulta de enfermagem, consultoria e grupos. Porto Alegre: Moriá; 2020. p.155-80.

14. Ribeiro GSC, Cavalcante TB, Santos KCB, Feitosa AHC, Silva BRS, Santos GL. Pacientes internados com feridas crônicas: um enfoque na qualidade de vida. Enferm Foco. 2019;10(2):70-5. doi: https://doi.org/10.21675/2357-707X.2019. v10.n2.1740

15. Mello AL, Backes DS, Terra MG, Rangel RF, Nietsche EA, Salbego C. (Re)pensando a educação permanente com base em novas metodologias de intervenção em saúde. Rev Cubana Enferm. 2017 [cited 2020 Aug 18];33(3):e1104. Available from: http://revenfermeria.sld.cu/index.php/enf/article/view/1104/285

\section{- Corresponding author:}

Amália de Fátima Lucena

Email: afatimalucena@gmail.com

\section{Associate editor:}

Dagmar Elaine Kaiser 